Article

\title{
Synthesis, X-ray Single-Crystal Analysis, and Anticancer Activity Evaluation of New Alkylsulfanyl-Pyridazino[4,5-b]indole Compounds as Multitarget Inhibitors of EGFR and Its Downstream PI3K-AKT Pathway
}

\author{
Eid E. Salama ${ }^{1, *(\mathbb{D}}$, Ibrahim O. Althobaiti ${ }^{1}$, Matti Haukka ${ }^{2} \mathbb{D}$ and Ahmed T. A. Boraei ${ }^{3, *}$ \\ 1 Department of Chemistry, College of Science and Arts, Jouf University, Qurayyat 75911, Saudi Arabia; \\ ioalthobaiti@ju.edu.sa \\ 2 Department of Chemistry, University of Jyväskylä, P.O. Box 35, FI-40014 Jyväskylä, Finland; \\ matti.o.haukka@jyu.fi \\ 3 Department of Chemistry, Faculty of Science, Suez Canal University, Ismailia 41522, Egypt \\ * Correspondence: eesalama@ju.edu.sa (E.E.S.); ahmed_tawfeek83@yahoo.com (A.T.A.B.)
}

check for updates

Citation: Salama, E.E.; Althobaiti, I.O.; Haukka, M.; Boraei, A.T.A. Synthesis, X-ray Single-Crystal Analysis, and Anticancer Activity Evaluation of New AlkylsulfanylPyridazino[4,5-b]indole Compounds as Multitarget Inhibitors of EGFR and Its Downstream PI3K-AKT Pathway. Crystals 2022, 12, 353. https:// doi.org/10.3390/cryst12030353

Academic Editors: Assem Barakat, Alexander S. Novikov and Ana M. Garcia-Deibe

Received: 12 February 2022

Accepted: 3 March 2022

Published: 4 March 2022

Publisher's Note: MDPI stays neutral with regard to jurisdictional claims in published maps and institutional affiliations.

Copyright: (C) 2022 by the authors. Licensee MDPI, Basel, Switzerland. This article is an open access article distributed under the terms and conditions of the Creative Commons Attribution (CC BY) license (https:/ / creativecommons.org/licenses/by/ $4.0 /)$.

\begin{abstract}
The alkylation of 3,5-dihydro-4H-pyridazino[4,5-b]indole-4-thione with benzyl bromide, ethyl chloroacetate, and allyl bromide in the presence of potassium carbonate $\left(\mathrm{K}_{2} \mathrm{CO}_{3}\right)$ yielded new alkylsulfanylpyridazino[4,5-b]indole derivatives (i.e., compounds 4-6). Hydrazinolysis of ester 6 resulted in hydrazide 7 . The structure of compound 6 was verified by X-ray single-crystal analysis. Among the synthesized compounds, compound $\mathbf{6}$ exhibited the most promising cytotoxicity toward MCF-7 cells with an $\mathrm{IC}_{50}$ value of $12 \mu \mathrm{M}$. It showed potential inhibition activity toward EGFR, PI3K, and AKT in MCF-7 cells, with 0.26-, 0.49-, and 0.31-fold reductions in concentration compared to an untreated control. Additionally, it showed apoptosis-inducing activity in MCF-7 cells (47.98-fold); overall apoptosis increased to $38.87 \%$ compared to $0.81 \%$ in the untreated control, which disrupted the cell cycle at pre-G1 and S phases. Moreover, compound 6 exhibited good binding affinities toward the tested proteins (EGFR, PI3K, and AKT) and had binding energies ranging from -15.87 to $-24.87 \mathrm{Kcal} / \mathrm{mol}$. It also formed good interactions with essential amino acids inside the binding sites. Hence, compound $\mathbf{6}$ is recommended as an anti-breast cancer chemotherapeutic due to its effects on the EGFR-PI3K-AKT pathway.
\end{abstract}

Keywords: pyridazino[4,5-b]indole; alkylation; anticancer activity; X-ray single crystal

\section{Introduction}

One of the most prevalent diseases that attacks any organ or part of the body is cancer. It is characterized by the uncontrollable and irregular growth of cells [1,2]. Therefore, scientists and researchers prepare a variety of chemicals to either be used in the treatment of cancer, improve medicines that are used in its treatment, or reduce its side effects on human health.

Pyridazino[4,5-b]indole's nucleus contains two heterocyclic compounds that interact with many receptors and are important to biological and metabolic processes within the body [3-6]. Because of their bioisosterism with $\gamma$ - and $\beta$-carboline, these two heterocyclic compounds have a wide range of uses in medicinal chemistry.

Pyridazino[4,5-b]indole derivatives have therapeutic effects as they act as thromboxane A2 synthetase inhibitors [7], antihypertensive MAO inhibitors [8], antihistaminic and HIV-1 reverse transcriptase inhibitors, antiarrhythmics [9], phosphatidylinositol 3-kinase (PI3K) inhibitors [10], blood platelet aggregation inhibitors, inotropics [11], serotonin antagonists [12], and anxiolytics [13], and they have antimicrobial and antiproliferative effects in different cell types [14]. Pyridazino[4,5-b]indole derivatives also have inhibitory effects 
against cancer cells such as human neuroblastoma IMR-32 cell lines (Figure 1), hepatocellular carcinoma Huh-7, human primary glioblastoma U-87, prostate carcinoma PC3, colorectal adenocarcinoma Caco2, breast cancer cells MDA-MB-231, colorectal carcinoma HCT-116, one normal cell line (fibroblasts), lung carcinoid NCI-H727, and MCF 7; additionally, they inhibit enzymes in cancer cells [15-19]. Moreover, pyridazino[4,5-b]indole derivatives provide powerful therapeutic effects for different diseases related to acute and chronic inflammation [20], neuroinflammation, and neoplastic progression [21].<smiles>Cc1n[nH]c(=O)c2c1c1cc(F)ccc1n2Cc1cn(Cc2ccccc2F)nn1</smiles><smiles>Cc1n[nH]c(=O)c2c1c1cc(F)ccc1n2Cc1cn(C2CCCCC2)nn1</smiles>

human neuroblastoma IMR-32 cell

Figure 1. Bioactive pyridazino[4,5-b]indole.

The resistance to drugs that target the epidermal growth factor receptor (EGFR), such as cetuximab, is a crucial hurdle in the research on effective therapies for neck and head squamous cell carcinoma. The phosphatidylinositol 3-kinase (PI3K)-Akt pathway was suggested as a contributor to the resistance of EGFR inhibitors because of its deep bond with the EGFR pathway. Understanding the function of each of the key proteins in this pathway is important for developing rational combination tactics that can overcome resistance [22].

Breast cancer is caused by a variety of factors (exogenous and endogenous), each of which has a different effect [23]. Due to its aggressive characteristics, invasive breast cancer is difficult to treat $[24,25]$. Breast cancer therapy is dependent on a mechanism that can be targeted by synthetic or natural substances that are approved as anticancer medicines [26,27]. Literature reviews [28-30] noted that many heterocyclic compounds have been created as anti-breast cancer therapies, such as pertuzumab, trastuzumab deruxtecan, trastuzumab emtansine, lapatinib, trastuzumab, and neratinib. There are four subtypes of tumors: luminal A, luminal B, human epidermal growth factor receptor 2 (HER2), and triple-negative breast cancer (TNBC). In this study, novel alkylated pyridazino[4,5b]indole derivatives were synthesized, and their activity toward breast cancer cell lines was evaluated.

\section{Materials and Methods}

\subsection{General Procedure}

Melting points were measured with the use of SMP10 apparatus in open capillaries and were uncorrected. Thin-layer chromatography (TLC) and UV light were used for monitoring reaction progress. Proton and carbon nuclear magnetic resonance $\left({ }^{1} \mathrm{H}-\right.$ and ${ }^{13} \mathrm{C}-\mathrm{NMR}$ ) were detected in $\mathrm{CDCl}_{3}$ and DMSO- $d_{6}$ and were recorded on Bruker $\mathrm{AC} 400$ and $100 \mathrm{MHz}$ spectrometers in tetramethylsilane as internal standard. Chemical shift values were evaluated in $\delta(\mathrm{ppm})$, and coupling constants values were set in Hz. Flash EA-1112 instrument was used for elemental analysis $(\mathrm{CHN})$ determination. X-ray single crystallographic analysis was collected on a Rigaku Oxford Diffraction Supernova diffractometer using $\mathrm{Cu} \mathrm{K} \alpha$ radiation. 


\subsection{Synthesis}

2.2.1. Synthesis of 3,5-Dihydro-4H-Pyridazino[4,5-b]indol-4-One (2)

A solution of $1.0 \mathrm{mmol}$ of ester 1 and $2.0 \mathrm{mmol}$ of hydrazine hydrate in $5 \mathrm{~mL}$ ethanol was kept under reflux for 3 hours and left to reach room temperature. Crystals of substance 2 formed and were collected by filtration and purified by recrystallization from ethanol.

Yield: $75 \%$, m.p. $>300{ }^{\circ} \mathrm{C}$ [Lit. [31,32] $\left.324-326{ }^{\circ} \mathrm{C}\right] .{ }^{1} \mathrm{H}$ NMR $\left(400 \mathrm{MHz}, \mathrm{DMSO}-d_{6}\right): \delta$ $7.33\left(\mathrm{dd}, 1 \mathrm{H}, J\right.$ J 7.2, 7.6 Hz, H-8 Ind.); $7.53\left(\mathrm{dd}, 1 \mathrm{H}, J 7.2,8.0 \mathrm{~Hz}, \mathrm{H}-7_{\text {Ind. }}\right) ; 7.63(\mathrm{~d}, 1 \mathrm{H}, J 8.4 \mathrm{~Hz}$, H-6 Ind. $\left._{\text {. }}\right) ; 8.16\left(\mathrm{~d}, 1 \mathrm{H}, J 8.0 \mathrm{~Hz}, \mathrm{H}-9_{\text {Ind. }}\right) ; 8.74\left(\mathrm{~s}, 1 \mathrm{H}, \mathrm{CH}_{\text {pyridazine }}\right) ; 12.66,12.76(2 \mathrm{~s}, 2 \mathrm{H}$, $\left.\mathrm{NH}_{\text {indole }}+\mathrm{NH}_{\text {pyridazine }}\right) \cdot{ }^{13} \mathrm{C}$ NMR $\left(100 \mathrm{MHz}\right.$, DMSO- $\left.d_{6}\right): \delta 113.45,117.98,121.26,121.79$, $121.89,127.44,132.14,133.78,139.39,156.19$ (see in Supplementary Materials). Elemental analysis calculated for $\left[\mathrm{C}_{10} \mathrm{H}_{7} \mathrm{~N}_{3} \mathrm{O}\right]: \mathrm{C}, 64.86 ; \mathrm{H}, 3.81 ; \mathrm{N}, 22.69 ; \mathrm{O}, 8.64$ vs. found: $\mathrm{C}, 64.66$; $\mathrm{H}, 3.91 ; \mathrm{N}, 22.55$.

\subsubsection{Synthesis of 3,5-Dihydro-4H-Pyridazino[4,5-b]indole-4-Thione (3)}

A $10.0 \mathrm{mmol}$ mixture of pyridazino[4,5-b]indol-4-one (i.e., substance 2), $25 \mathrm{~mL}$ of dry pyridine, and $(2.25 \mathrm{~g}, 10 \mathrm{mmol}) \mathrm{P}_{2} \mathrm{~S}_{5}$ was refluxed for $6 \mathrm{~h}$. It was then cooled and poured into $250 \mathrm{~mL}$ ice water. The generated precipitate 3 was then filtered and dried.

Yield: $79 \%$, m.p. $>300{ }^{\circ} \mathrm{C} .{ }^{1} \mathrm{H}$ NMR $\left(400 \mathrm{MHz}, \mathrm{DMSO}-d_{6}\right): \delta 7.37(\mathrm{dd}, 1 \mathrm{H}, J 7.6, J 8 \mathrm{~Hz})$; 7.59 (dd, $1 \mathrm{H}, J$ 7.6, J $8 \mathrm{~Hz}) ; 7.75(\mathrm{~d}, 1 \mathrm{H}, J 8.0 \mathrm{~Hz}) ; 8.25$ (d, $1 \mathrm{H}, J 8.0 \mathrm{~Hz}) ; 9.19(\mathrm{~s}, 1 \mathrm{H}) ; 12.54$ (s, $1 \mathrm{H}, \mathrm{NH}$ indole); 14.47 (s, $1 \mathrm{H}, \mathrm{NH}) .{ }^{13} \mathrm{C}$ NMR (100 MHz, DMSO- $\left.d_{6}\right): \delta 112.24,113.80$, $120.78,122.40,122.82,128.59,137.79,140.56,140.56,140.81,169.24$ (see in Supplementary Materials). Elemental analysis calculated for $\left[\mathrm{C}_{10} \mathrm{H}_{7} \mathrm{~N}_{3} \mathrm{~S}\right]$ : $\mathrm{C}, 59.68 ; \mathrm{H}, 3.51 ; \mathrm{N}, 20.88 ; \mathrm{S}$, 15.93 vs. found: $\mathrm{C}, 59.71 ; \mathrm{H}, 3.55 ; \mathrm{N}, 20.93 ; \mathrm{S}, 15.88$.

\subsubsection{Alkylation of Pyridazino[4,5-b]indole-4-Thione (3)}

Compound $3(1.0 \mathrm{mmol})$ and $2.2 \mathrm{mmol}$ of potassium carbonate were stirred in $10 \mathrm{~mL}$ acetone at room temperature for $1 \mathrm{~h}$. Alkyl halide (benzyl bromide, allyl bromide, and ethyl chloroacetate) was then added drop by drop. Stirring was continued overnight, followed by removing of solvent under vacuum, and then addition of water. The solution was then filtered, and the precipitate was dried and recrystallized from ethanol to yield pure products $4-6$.

- 4-(Benzylsulfanyl)-5H-Pyridazino[4,5-b]indole (4)

Yield: $65 \%$, m.p. $254-255^{\circ} \mathrm{C} .{ }^{1} \mathrm{H}$ NMR (400 MHz, DMSO- $\left.d_{6}\right): \delta 4.80\left(\mathrm{~s}, 2 \mathrm{H}, \mathrm{SCH}_{2}\right)$; 7.24-7.41 (m, $4 \mathrm{H}) ; 7.51(\mathrm{~d}, 2 \mathrm{H}, J 7.2 \mathrm{~Hz}) ; 7.62(\mathrm{ddd}, 1 \mathrm{H}, J$ 8.1, 8.0, $0.8 \mathrm{~Hz}) ; 7.70(\mathrm{~d}, 1 \mathrm{H}, J$ $8.2 \mathrm{~Hz}) ; 8.32$ (d, $1 \mathrm{H}, J 8.0 \mathrm{~Hz}) ; 9.76(\mathrm{~s}, 1 \mathrm{H}) ; 12.34$ (s, $\left.1 \mathrm{H}, \mathrm{NH}_{\mathrm{ind}}\right) .{ }^{13} \mathrm{C} \mathrm{NMR}(100 \mathrm{MHz}$, DMSO- $\left.d_{6}\right): \delta 33.34\left(\mathrm{SCH}_{2}\right), 113.31,117.31,119.75,121.84,122.45,127.68,128.91,129.09$, $129.52,138.22,140.01,142.68,146.57$ (see in Supplementary Materials). Elemental analysis calculated for $\left[\mathrm{C}_{17} \mathrm{H}_{13} \mathrm{~N}_{3} \mathrm{~S}\right]$ : C, $70.08 ; \mathrm{H}, 4.50 ; \mathrm{N}, 14.42 ; \mathrm{S}, 11.00$ vs. found: $\mathrm{C}, 70.21 ; \mathrm{H}, 4.59$; $\mathrm{N}, 14.44 ; \mathrm{S}, 11.08$.

- 4-(Allylsulfanyl)-5H-Pyridazino[4,5-b]indole (5)

Yield: 71\%, m.p. $252-253{ }^{\circ} \mathrm{C} .{ }^{1} \mathrm{H}$ NMR $\left(400 \mathrm{MHz}, \mathrm{DMSO}-d_{6}\right): \delta 4.20(\mathrm{~d}, 2 \mathrm{H}, J 6.4 \mathrm{~Hz}$, $\left.\mathrm{SCH}_{2}\right) ; 5.14\left(\mathrm{~d}, 1 \mathrm{H}, J_{\mathrm{cis}} 10.0 \mathrm{~Hz}, \mathrm{H}_{\mathrm{cis}}\right) ; 5.36\left(\mathrm{~d}, 1 \mathrm{H}, J_{\text {trans }} 17.2 \mathrm{~Hz}, \mathrm{H}_{\text {trans }}\right) ; 6.03-6.13(\mathrm{~m}, 1 \mathrm{H}$, $\left.-\mathrm{CH}=\mathrm{CH}_{2}\right) ; 7.39(\mathrm{dd}, 1 \mathrm{H}, J 7.2,7.6 \mathrm{~Hz}) ; 7.63(\mathrm{dd}, 1 \mathrm{H}, J 7.2,8.0 \mathrm{~Hz}) ; 7.71(\mathrm{~d}, 1 \mathrm{H}, J 8.0 \mathrm{~Hz}) ; 8.31$ (d, $1 \mathrm{H}, J 7.6 \mathrm{~Hz}) ; 9.74(\mathrm{~s}, 1 \mathrm{H}) ; 12.32\left(\mathrm{~s}, 1 \mathrm{H}, \mathrm{NH}_{\text {ind }}\right) .{ }^{13} \mathrm{C}$ NMR $\left(100 \mathrm{MHz}\right.$, DMSO- $\left.d_{6}\right): \delta 32.22$ $\left(\mathrm{SCH}_{2}\right), 113.34,117.34,118.61,119.80,121.81,122.41,129.05,134.10,134.26,140.11,142.55$, 146.27 (see in Supplementary Materials). Elemental analysis calculated for $\left[\mathrm{C}_{13} \mathrm{H}_{11} \mathrm{~N}_{3} \mathrm{~S}\right]$ : $\mathrm{C}$, 64.71; H, 4.59; N, 17.41; S, 13.29 vs. found: $\mathrm{C}, 64.59 ; \mathrm{H}, 4.63 ; \mathrm{N}, 17.33 ; \mathrm{S}, 13.31$.

- $\quad$ Ethyl 2-((5H-Pyridazino[4,5-b]indol-4-yl)sulfanyl)acetate (6)

Yield: 83\%, m.p. $218-219{ }^{\circ} \mathrm{C} .{ }^{1} \mathrm{H}$ NMR $\left(600 \mathrm{MHz}, \mathrm{DMSO}-d_{6}\right): \delta 1.19(\mathrm{t}, 3 \mathrm{H}, J 7.1 \mathrm{~Hz}$, $\left.\mathrm{CH}_{3}\right) ; 4.14\left(\mathrm{q}, 2 \mathrm{H}, J 7.1 \mathrm{~Hz}, \mathrm{CH}_{2}\right) ; 4.40\left(\mathrm{~s}, 2 \mathrm{H}, \mathrm{SCH}_{2}\right) ; 7.41(\mathrm{dd}, 1 \mathrm{H}, J$ 7.3, $7.7 \mathrm{~Hz}) ; 7.65$ (dd, 1 H, J 7.4, 7.9 Hz); $7.72(\mathrm{~d}, 1 \mathrm{H}, J 8.2 \mathrm{~Hz}) ; 8.33(\mathrm{~d}, 1 \mathrm{H}, J 8.0 \mathrm{~Hz}) ; 9.74$ (s, $1 \mathrm{H}) ; 12.48$ (s, 
$\left.1 \mathrm{H}, \mathrm{NH}_{\text {ind }}\right) .{ }^{13} \mathrm{C}$ NMR $\left(150 \mathrm{MHz}, \mathrm{DMSO}-d_{6}\right): \delta 14.5\left(\mathrm{CH}_{3}\right), 31.76\left(\mathrm{SCH}_{2}\right), 61.55\left(\mathrm{OCH}_{2}\right)$, $113.33,117.34,121.90,122.51,129.18,133.57,139.06,142.76,145.50,169.09(\mathrm{C}=\mathrm{O})$ (see in Supplementary Materials). Elemental analysis calculated for $\left[\mathrm{C}_{14} \mathrm{H}_{13} \mathrm{~N}_{3} \mathrm{O}_{2} \mathrm{~S}\right]$ : $\mathrm{C}, 58.52 ; \mathrm{H}$, 4.56; N, 14.62; O, 11.14; S, 11.16 vs. found: C, 58.67; H, 4.59; N, 14.53; S, 11.22.

\subsubsection{Hydrazinolysis of Ester 6}

Ester $6(1.0 \mathrm{mmol})$ and $2.0 \mathrm{mmol}$ of hydrazine hydrate in $10 \mathrm{~mL}$ of ethanol were refluxed for $2 \mathrm{~h}$ and left to cool. Crystals formed and were collected by filtration, dried, and purified through recrystallization from ethanol.

- 2-((5H-Pyridazino[4,5-b]indol-4-yl)thio)acetohydrazide (7)

Yield: 80\%, m.p. $241-242{ }^{\circ} \mathrm{C} .{ }^{1} \mathrm{H}$ NMR (400 MHz, DMSO- $\left.d_{6}\right): \delta 4.25\left(\mathrm{~s}, 2 \mathrm{H}, \mathrm{SCH}_{2}\right)$; 4.35 (brs, $\left.2 \mathrm{H}, \mathrm{NH}_{2}\right) ; 7.40$ (dd, $\left.1 \mathrm{H}, J 7.2,7.6 \mathrm{~Hz}\right) ; 7.63(\mathrm{dd}, 1 \mathrm{H}, J$ 7.4, $7.9 \mathrm{~Hz}) ; 7.71$ (d, $1 \mathrm{H}, J$ $8.4 \mathrm{~Hz}) ; 8.31$ (d, $1 \mathrm{H}, J 8.0 \mathrm{~Hz}) ; 9.42$ (brs, $1 \mathrm{H}, \mathrm{NH}) ; 9.74(\mathrm{~s}, 1 \mathrm{H}) ; 12.44\left(\mathrm{~s}, 1 \mathrm{H}, \mathrm{NH}_{\text {ind }}\right) .{ }^{13} \mathrm{C}$ NMR (100 MHz, DMSO-d 6 ): $\delta 31.95\left(\mathrm{SCH}_{2}\right), 113.34,117.30,119.75,121.84,122.42,129.09$, 133.77, 140.12, 142.62, 146.42, $167.34(\mathrm{C}=\mathrm{O})$ (see in Supplementary Materials). Elemental analysis calculated for $\left[\mathrm{C}_{12} \mathrm{H}_{11} \mathrm{~N}_{5} \mathrm{OS}\right]$ : $\mathrm{C}, 52.73 ; \mathrm{H}, 4.06 ; \mathrm{N}, 25.62 ; \mathrm{O}, 5.85 ; \mathrm{S}, 11.73$ vs. found: C, 52.83; H, 4.05; N, 25.52; S, 11.70 .

\subsection{Biology}

\subsubsection{Cytotoxicity}

MCF-7 and normal breast MCF-10A cell lines were collected from National Cancer Institute in Cairo, A.R.E, and grown in RPMI-1640 medium L-glutamine. The cells were grown in $10 \%$ fetal bovine serum (FBS) and 1\% penicillin-streptomycin. All samples were cultured at 37 degrees Celsius in a $5 \% \mathrm{CO}_{2}$ gas. On the second day, cells were grown in triplicate on a 96-well plate at a density of $5 \times 10^{4}$ cells and incubated with the investigated compounds at $0.01,0.1,1,10$, and $100 \mathrm{mM}$. MTT solution was used to determine cell viability. The plate was cultured for 3 hours. An ELISA microplate reader was used to measure the absorbance. The viability was determined by comparing it to the control group, and the IC50 values were recorded [31].

\subsubsection{Enzymatic Targeting}

To assess the inhibitory potency of compound 6 against the EGFR, an EGFR test kit (ADP-GloTM kinase assay, Cat No. V9261, Promega, Madison, WI, USA), a PI3K assay kit (Cat No. MBS268899, USA), and an AKT assay kit (Catalog \#: MBS9511022, USA) were used. The percentage inhibition of autophosphorylation by substances was estimated using the following equation [32]:

$$
\text { Percentage inhibition }=100-\left[\frac{\text { Control }}{\text { Treated }}-\text { Control }\right]
$$

\subsubsection{Apoptosis Investigation}

MCF-7 cells were incubated overnight in 6-well culture plates $\left(3-5 \times 10^{5}\right.$ cells per well) and then treated for $48 \mathrm{~h}$ with compound 7. Afterward, the cells were incubated in a $100 \mu \mathrm{L}$ solution of Annexin binding buffer $\left(25 \mathrm{mM} \mathrm{CaCl}_{2}, 1.4 \mathrm{M} \mathrm{NaCl}\right.$, and $0.1 \mathrm{M}$ Hepes-NaOH, pH 7.4) in the dark for 30 min with Annexin V-FITC solution (1:100) and propidium iodide (PI) at a concentration equivalent to $10 \mathrm{~g} / \mathrm{mL}$. The labeled cells were then extracted using the Cytoflex FACS machine. CytExpert software was used to analyze the data [33].

\subsection{Molecular Docking}

The investigated compounds were docked against the protein structures of EGFR $(\mathrm{PDB}=1 \mathrm{M} 17), \mathrm{PI} 3 \mathrm{~K}(\mathrm{PDB}=5 \mathrm{JHB})$, and AKT $(\mathrm{PDB}=3 \mathrm{KQQ})$ using MOE-2019 software. MOE-2019 was used to improve protein and ligand structures and to favor them energetically. Binding activities interpreted molecular docking results in terms of binding energy and ligand-receptor interactions. Visualization was then conducted with Chimera. 


\section{Results and Discussion}

\subsection{Chemistry}

The reaction of hydrazine hydrate with ethyl 3-formyl- $1 H$-indole-2-carboxylate (i.e., ester 1) in ethanol afforded 3,5-dihydro-4H-pyridazino[4,5-b]indol-4-one (i.e., substance 2). Thionation of substance 2 to a thione (i.e., compound 3 ) was conducted using $\mathrm{P}_{2} \mathrm{~S}_{5}$ in pyridine [34,35]. The structure of compound 3 was deduced from ${ }^{1} \mathrm{H}$ and ${ }^{13} \mathrm{C}$ NMR spectra, which showed an indole NH signal at $12.54 \mathrm{ppm}$ and a pyridazine NH signal at $14.47 \mathrm{ppm}$. A thione tautomer was deduced from a thiocarbonyl $(C=S)$ signal at 169.24 ppm. Alkylation of thionated compound 3 with benzyl bromide, allyl bromide, and ethyl chloroacetate was achieved in the presence of potassium carbonate and acetone. S-alkylation was confirmed from ${ }^{13} \mathrm{C}$ NMR signals found at 33.34, 32.22, and 31.76 ppm in alkylated products 4-6, respectively (Scheme 1).<smiles>CCOC(=O)c1c(C=O)[nH]c2ccccc12</smiles><smiles></smiles><smiles>[R]C(=O)C(C([R])=O)[C@H]([R])C</smiles><smiles>S=c1[nH]ncc2c1[nH]c1ccccc12</smiles><smiles>c1ccc(CSc2nncc3c2[nH]c2ccccc23)cc1</smiles><smiles>C=CCSc1nncc2c1[nH]c1ccccc12</smiles>

4<smiles>CCOC(=O)CSc1nncc2c1[nH]c1ccccc12</smiles>

6

Scheme 1. Synthesis and alkylation of 3,5-dihydro-4H-pyridazino[4,5-b]indole-4-thione (i.e., compound 3).

The reaction of hydrazine hydrate with ester 6 in ethanol led to the conversion of the ester group to hydrazide and the formation of product 7. The NMR of the hydrazide showed hydrazide group (-CONHNH 2$)$ proton signals at 4.35 and $9.42 \mathrm{ppm}$ and a carbonyl signal at $167.34 \mathrm{ppm}$ (Scheme 2). 


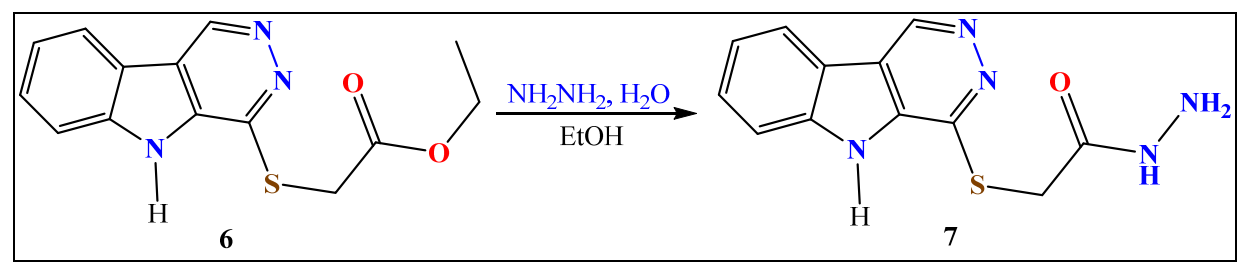

Scheme 2. Hydrazinolysis of ester 6 .

\subsection{X-ray Single-Crystal Analysis and Structural Determinations}

A single crystal of compound $\mathbf{6}$ was grown via the slow evaporation of ethanol. Crystal data showed that the compound had an empirical formula of $\mathrm{C}_{14} \mathrm{H}_{13} \mathrm{~N}_{3} \mathrm{O}_{2} \mathrm{~S}$ and crystallized in an orthorhombic crystal system (Pccn space group) (Figure 2). Molecules were stabilized in a 3D molecular packing network by strong, classical intermolecular hydrogen bonding, and the most important bond was $\mathrm{N}(1)-\mathrm{H}(1) \ldots \mathrm{N}(2)$ (Figure 3).

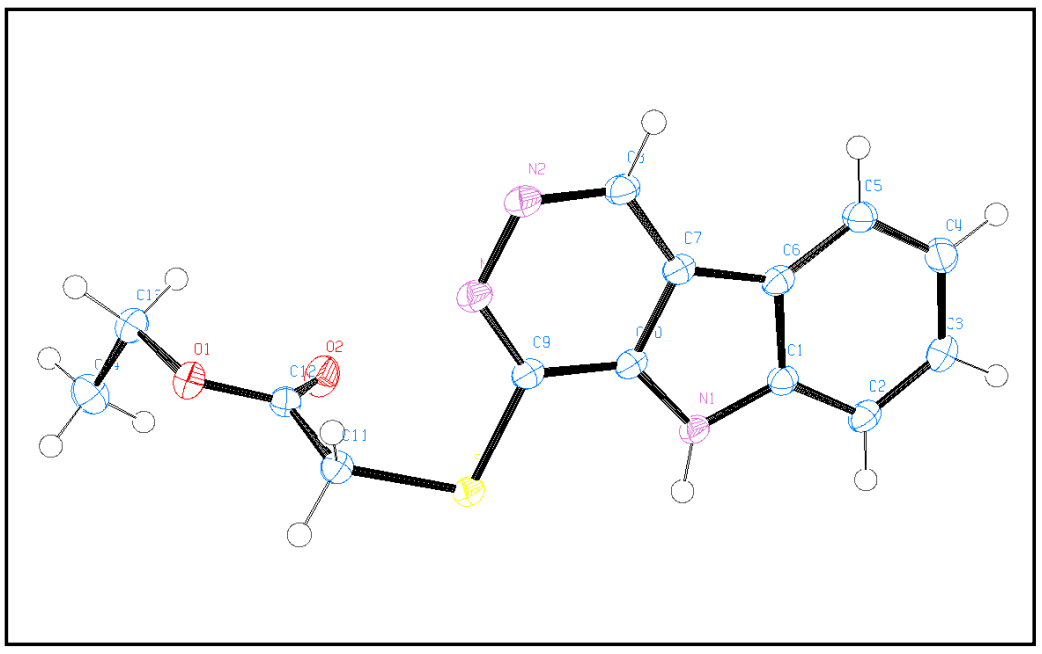

Figure 2. ORTEP projection of compound 6 (CCDC 2133074, see in Supplementary Materials).

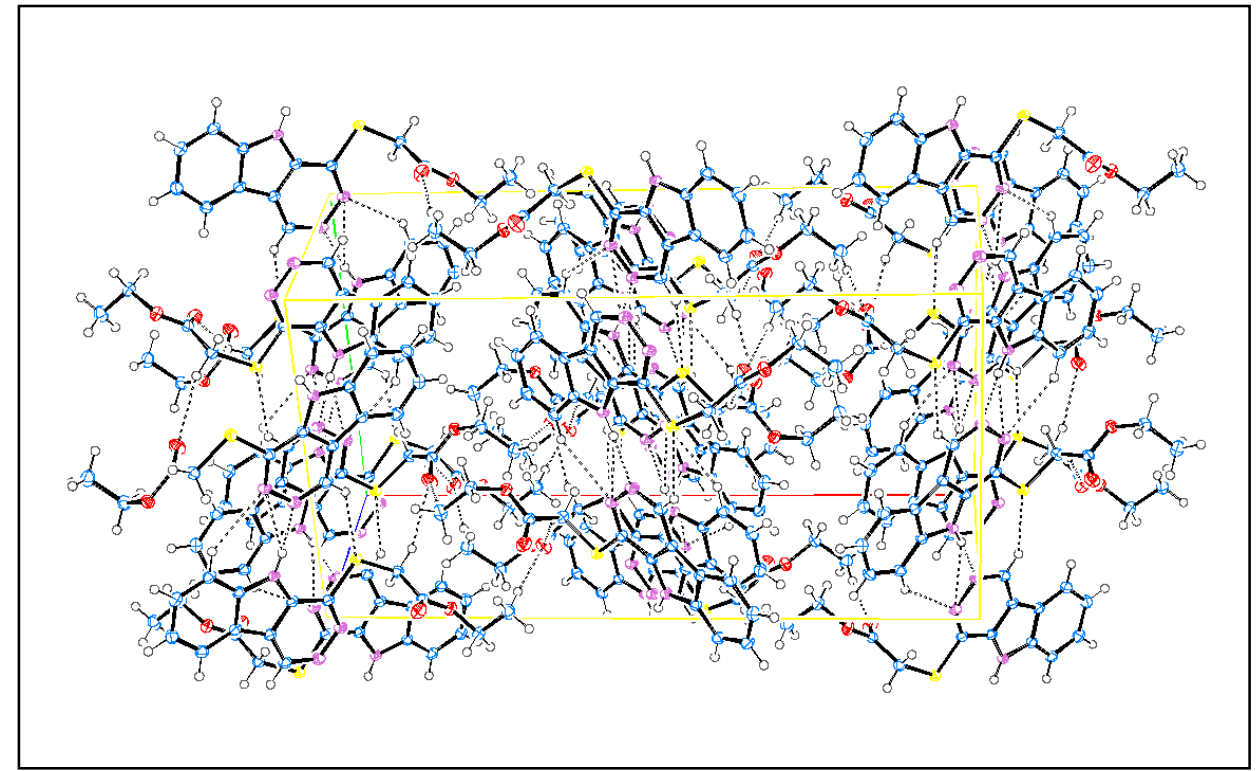

Figure 3. Packing diagram of compound 6. 
The crystallographic details are summarized in Table 1.

Table 1. Crystal data set of target molecule 6 .

\begin{tabular}{cc}
\hline Compound & 6 \\
\hline CCDC & 2133074 \\
Empirical formula & $\mathrm{C}_{14} \mathrm{H}_{13} \mathrm{~N}_{3} \mathrm{O}_{2} \mathrm{~S}$ \\
FW & 287.33 \\
Temp $(\mathrm{K})$ & $120(2)$ \\
$\lambda(\AA)$ & 1.54184 \\
Crystal system & Orthorhombic \\
Space group & Pccn \\
$a(\AA)$ & $23.7290(2)$ \\
$b(\AA)$ & $13.06630(10)$ \\
$c(\AA)$ & $8.45260(10)$ \\
$V\left(\AA \AA^{3}\right)$ & $2620.73(4)$ \\
$Z$ & 8 \\
$\rho_{\text {calc }}\left(\mathrm{Mg} / \mathrm{m}^{3}\right)$ & 1.456 \\
$\mu(\mathrm{Mo} \mathrm{K} \alpha)\left(\mathrm{mm}^{-1}\right)$ & 2.248 \\
No. reflns. & 31606 \\
Unique reflns. & 2768 \\
Completeness to $\theta=67.684^{\circ}$ & $100.0 \%$ \\
GOOF $\left(\mathrm{F}^{2}\right)$ & 1.038 \\
$\mathrm{R}_{\text {int }}$ & 0.0335 \\
$R 1^{\mathrm{a}}(I \geq 2 \sigma)$ & 0.0284 \\
$w R_{2}{ }^{\mathrm{b}}(I \geq 2 \sigma)$ & 0.0764 \\
\hline
\end{tabular}

${ }^{\mathrm{a}} R 1=\Sigma|| F_{\mathrm{o}}|-| F_{\mathrm{c}}|| / \Sigma\left|F_{\mathrm{o}}\right| \cdot{ }^{\mathrm{b}} w R_{2}=\left\{\Sigma\left[w\left(F_{\mathrm{o}}{ }^{2}-F_{\mathrm{c}}{ }^{2}\right)^{2}\right] / \Sigma\left[w\left(F_{\mathrm{o}}{ }^{2}\right)^{2}\right]\right\}^{1 / 2}$.

\subsection{Biology}

\subsubsection{Cytotoxic Activity}

The cytotoxic activity of the synthesized compounds was tested against the breast MCF-7 cancer cell line. The results illustrated in Table 2 revealed that compounds 2, 3, and 7 showed weak activity with $\mathrm{IC}_{50}$ 's of $37.5,94.3$, and $39.9 \mu \mathrm{M}$, while compounds 1,4 , and 6 showed promising cytotoxic activity, especially the latter, which had an $\mathrm{IC}_{50}$ value of $12 \mu \mathrm{M}$. Therefore, compound 6 was further screened for enzymatic targeting. Additionally, compound 6 was tested against normal breast MCF-10A cells for safety. Compared with Staurosporin, which had an $\mathrm{IC}_{50}$ value of $21.43 \mu \mathrm{M}$, compound 6 exhibited poor cytotoxic activity against normal cells with an $\mathrm{IC}_{50}$ value of $75.13 \mu \mathrm{M}$. Hence, compound 6 was selective in cytotoxicity against MCF-7 cells.

Table 2. $\mathrm{IC}_{50}$ values of the tested compounds against MCF-7 lines using the MTT assay.

\begin{tabular}{ccc}
\hline Compound & IC $_{\mathbf{5 0}} \pm$ SD $^{*, \#}(\mu \mathrm{M}) / \mathbf{M C F 7}$ & IC $_{\mathbf{5 0}} \pm$ SD $^{*, \#}(\boldsymbol{\mu M}) / \mathbf{M C F}-\mathbf{1 0 A}$ \\
\hline $\mathbf{( 1 )}$ & $19.7 \pm 2.31$ & - \\
\hline $\mathbf{( 2 )}$ & $37.5 \pm 1.95$ & - \\
\hline $\mathbf{( 3 )}$ & $94.3 \pm 4.9$ & - \\
\hline $\mathbf{( 4 )}$ & $20.4 \pm 1.06$ & - \\
\hline $\mathbf{( 6 )}$ & $12.0 \pm 0.63$ & $75.13 \pm 1.87$ \\
\hline $\mathbf{( 7 )}$ & $39.9 \pm 2.07$ & - \\
\hline Staurosporin & $8.32 \pm 0.43$ & $21.43 \pm 1.06$ \\
\hline
\end{tabular}

* Values are expressed as mean \pm SD of three independent triplets $(\mathrm{n}=3) .{ }^{\text {\# }}$ A nonlinear regression dose-inhibition curve was used to calculate $\mathrm{IC}_{50}$ values in Excel. 


\subsubsection{Enzymatic Targeting}

The EGFR-PI3K-AKT-mTOR signaling cascade is involved in a variety of cell activities that contribute to tumor progression, including cell growth, proliferation, survival, metabolism, apoptosis, and differentiation [36]. To investigate effective molecular targets of cytotoxic activity, compound 6, which had the highest cytotoxic activity toward MCF-7 cells, was tested against EGFR, PI3K, and AKT inhibition.

As seen in Table 3, in the presence of compound 6, EGFR concentrations decreased 0.26fold from $730 \mathrm{pg} / \mathrm{mL}$ to $191 \mathrm{pg} / \mathrm{mL}$. In addition, compound 6 reduced PI3K concentrations, compared with untreated controls, from $6.64 \mathrm{ng} / \mathrm{mL}$ to $3.28 \mathrm{ng} / \mathrm{mL}$, which was a 0.49 -fold reduction. Furthermore, AKT concentrations were reduced 0.31 -fold from $45.39 \mathrm{ng} / \mathrm{mL}$ to $14.06 \mathrm{pg} / \mathrm{mL}$ when compound 6 was added. Our PI3K inhibitory activity results are equivalent with Nafie et al. [37], who showed that a novel pyridazino[4,5-b]indole scaffold may be utilized as a PI3K inhibitor in the treatment of breast cancer.

Table 3. Activity of tested compound 6 against EGFR, PI3K, and AKT pathways in MCF-7 cells.

\begin{tabular}{cccc}
\hline Compound & $\begin{array}{c}\text { EGFR } \\
(\mathbf{p g} / \mathbf{m L})\end{array}$ & $\begin{array}{c}\text { PI3K } \\
(\mathbf{n g} / \mathbf{m L})\end{array}$ & $\begin{array}{c}\text { AKT } \\
(\mathbf{n g} / \mathbf{m L})\end{array}$ \\
\hline Control & $730 \pm 62.2$ & $6.638 \pm 0.28$ & $45.39 \pm 3.74$ \\
\hline Treated with 6 & $191.3 \pm 7.3$ & $3.28 \pm 0.09$ & $14.06 \pm 0.5$ \\
\hline
\end{tabular}

* Values are expressed as mean \pm SD of three independent replicates.

\subsubsection{Apoptotic Investigation}

\section{- $\quad$ Annexin V/PI Staining}

To study the apoptotic and necrotic activity of the investigated compound, flow cytometric examinations of Annexin V/PI staining in treated and untreated MCF-7 cells with compound $6\left(\mathrm{IC}_{50}=12 \mathrm{mM}, 48 \mathrm{~h}\right)$ were conducted.

Compound 6 enhanced overall apoptosis by $38.87 \%$ (13.81\% for late and $25.06 \%$ for early) compared to $0.81 \%$ ( $0.15 \%$ for late and $0.66 \%$ for early) for the control, as shown in Figure 4. This compound also enhanced necrotic breast cancer cell death 5.39-fold; necrotic cell death was enhanced by $7.45 \%$ compared to $1.38 \%$. As a result, apoptosis was adopted over necrosis as the mode of action.
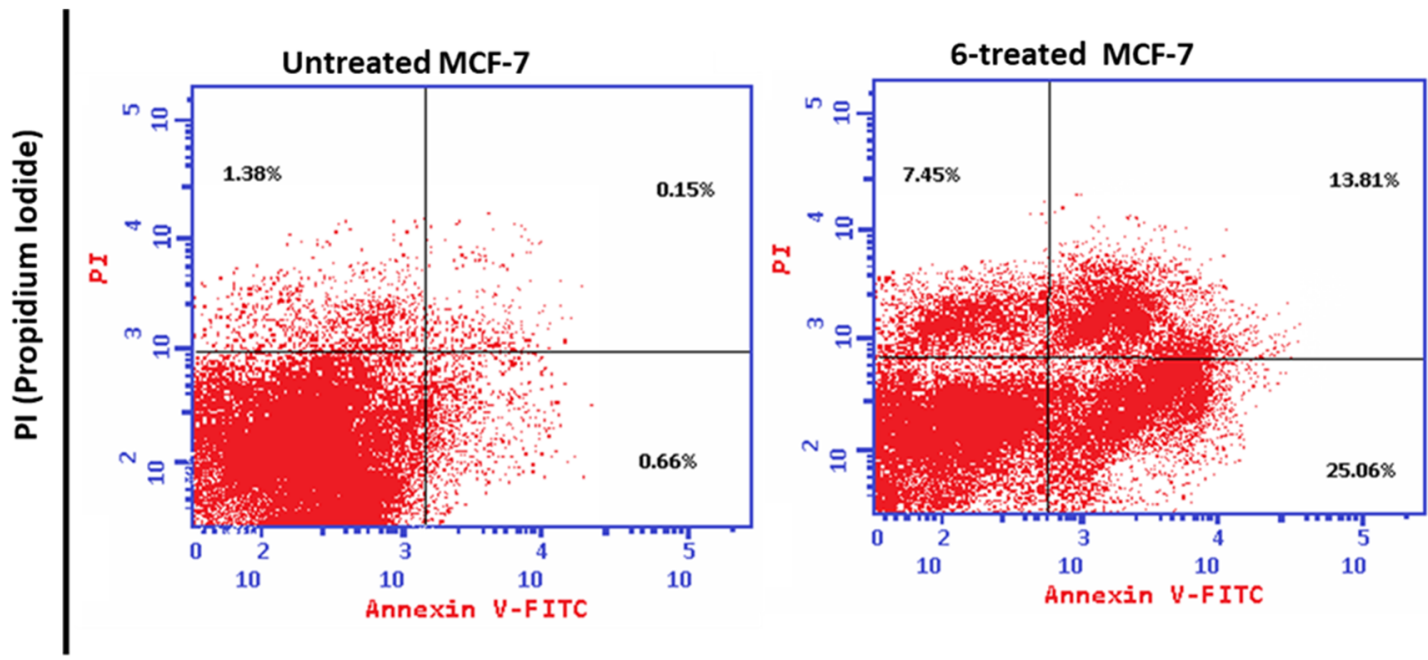

Annexin V-FITC

Figure 4. Cryptographs of Annexin V/Propidium Iodide staining of (left) untreated and (right) 6-treated MCF-7 cells with $\mathrm{IC}_{50}$ values, $48 \mathrm{~h}$. Q1-UL (necrosis, AV-/PI+), Q2-UR (late apoptotic cells, AV+/PI+), Q3-LL (normal cells, AV-/PI-), and Q4-LR (early apoptotic cells, AV+/PI-). 


\section{- Cell Cycle Analysis}

Cell cycle analysis was used to detect at which phase cells were arrested in both treated and untreated MCF-7 cells for the purpose of investigating the cell population percentage with cytotoxic chemicals after treatment in each cell phase. Figure 5 shows that the compound treatment increased the cell population by $46.32 \%$ in pre-G phase compared to $2.19 \%$ in the control and by $46.12 \%$ in S phase compared to $33.61 \%$ in the control, while the cell population was not significantly decreased. These findings are consistent with previous studies [38], which evaluated apoptosis-inducing activity using flow cytometric apoptosis and cell cycle analyses.

\section{A}

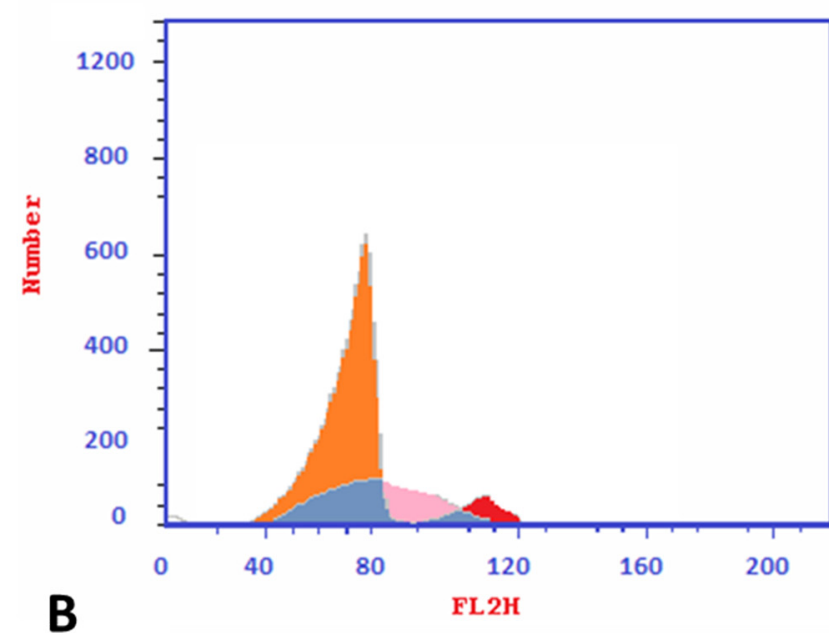

Unțreated MCF-7

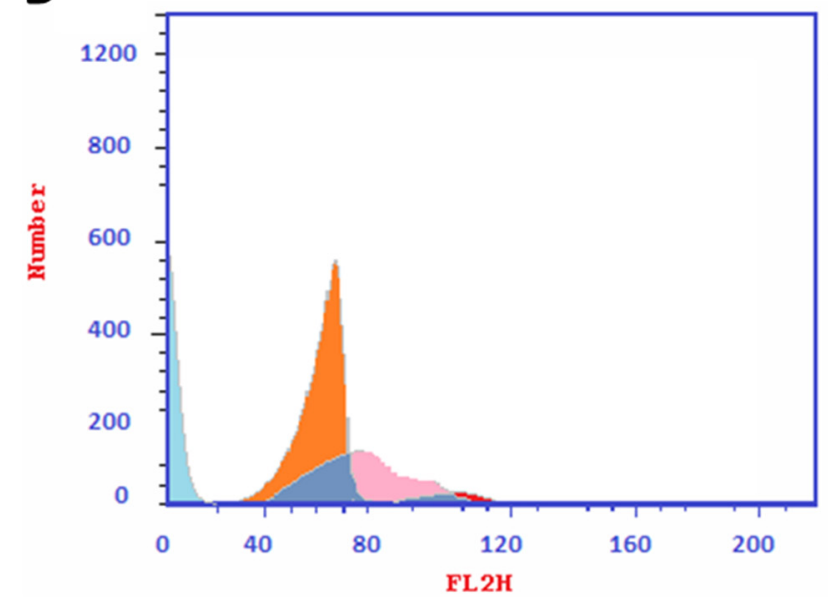

6-treated MCF-7

Diploid 100\%

\begin{tabular}{cl}
\hline \%pre G & $46.32 \%$ \\
\hline \%DIP G1 & $45.62 \%$ \\
\%DIP G2/M & $8.26 \%$ \\
\hline \%DIP S & $46.12 \%$ \\
& \\
\%CV & 4.93 \\
& \\
Aggregates : & $2.27 \%$ \\
Cell debris : & $1.61 \%$
\end{tabular}

Figure 5. Histograms of DNA content using flow-cytometry-aided cell cycle analyses of (A) untreated and (B) 6-treated MCF-7 cells ( $\mathrm{IC}_{50}=12 \mu \mathrm{M}, 48 \mathrm{~h}$ ), with the percentage of cell population at G1, S, and $\mathrm{G} 2 / \mathrm{M}$ phases.

\subsection{Molecular Docking}

To investigate the mechanism behind compound 6's promising cytotoxic and inhibitory activities toward EGFR, PI3K, and AKT, a study of molecular docking was conducted for these three proteins. Compound $\mathbf{6}$ exhibited good binding affinities toward the tested proteins of EGFR, PI3K, and AKT, and the binding energies ranged from -15.87 to $-24.87 \mathrm{Kcal} / \mathrm{mol}$. In addition, it formed good interactions with the key amino acids inside the bindings sites; hence, it maintained the binding interaction as the ligands cocrystallized (Figure 6). Compound 6 formed one hydrogen bond interaction with Met 769 inside the EGFR binding site. It made one hydrogen bond with Val 882 inside the PI3K binding site and one hydrogen bond with Asp 292 and arene-cation interactions with Lys 179 inside the 
AKT binding site. These findings of inhibiting EGFR, PI3K, and AKT agreed with previous studies using molecular docking approaches.

\section{A: EGFR}

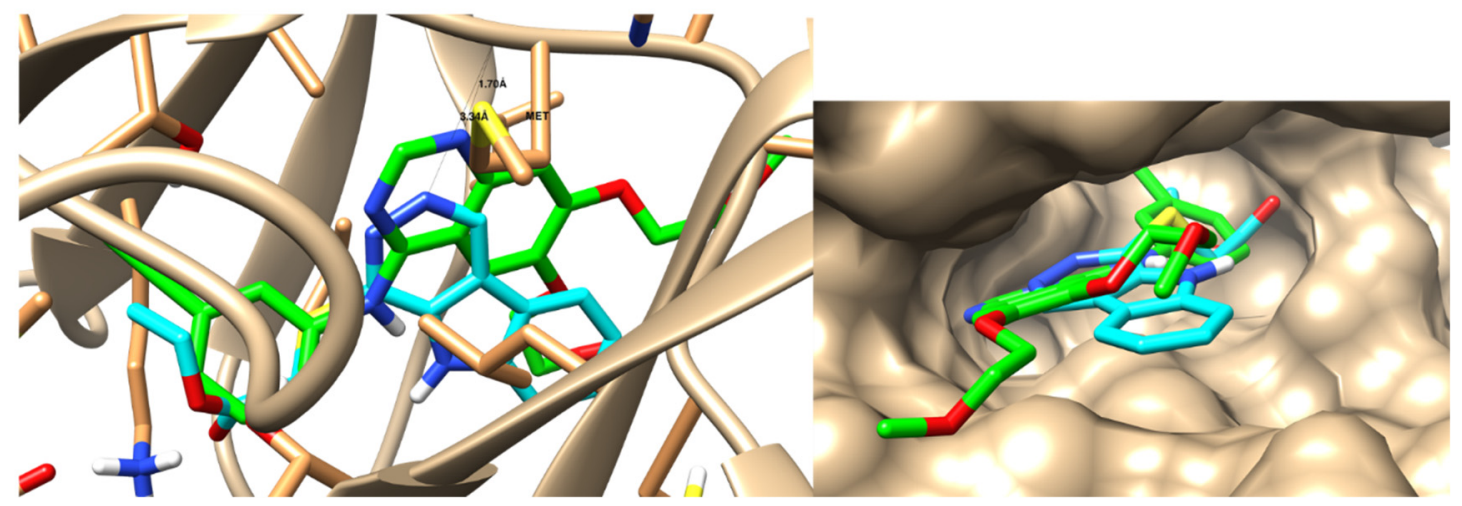

B: PI3K

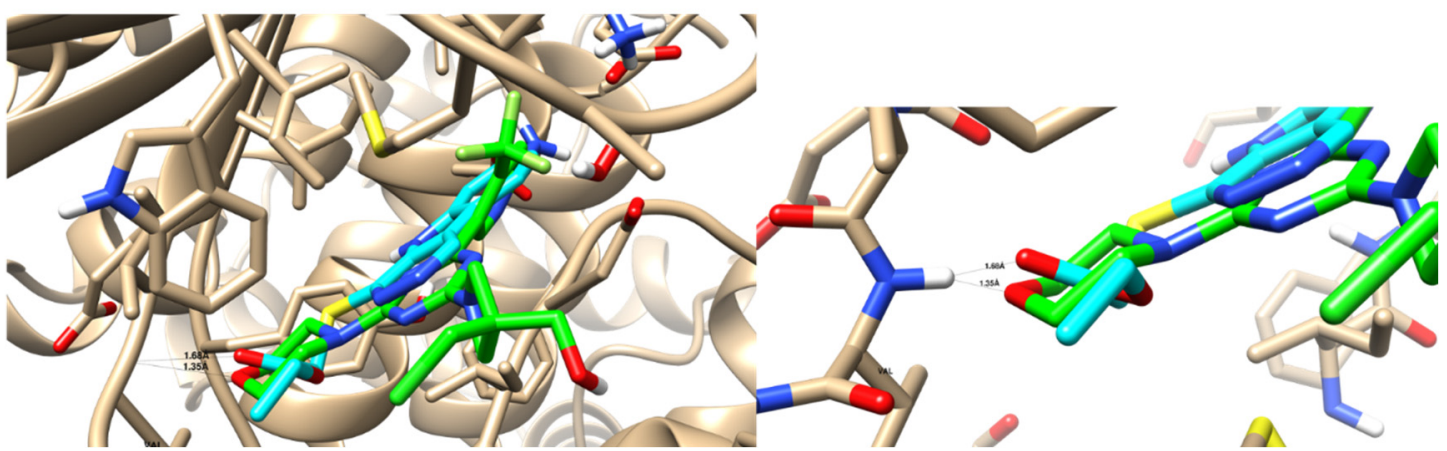

C: AKT

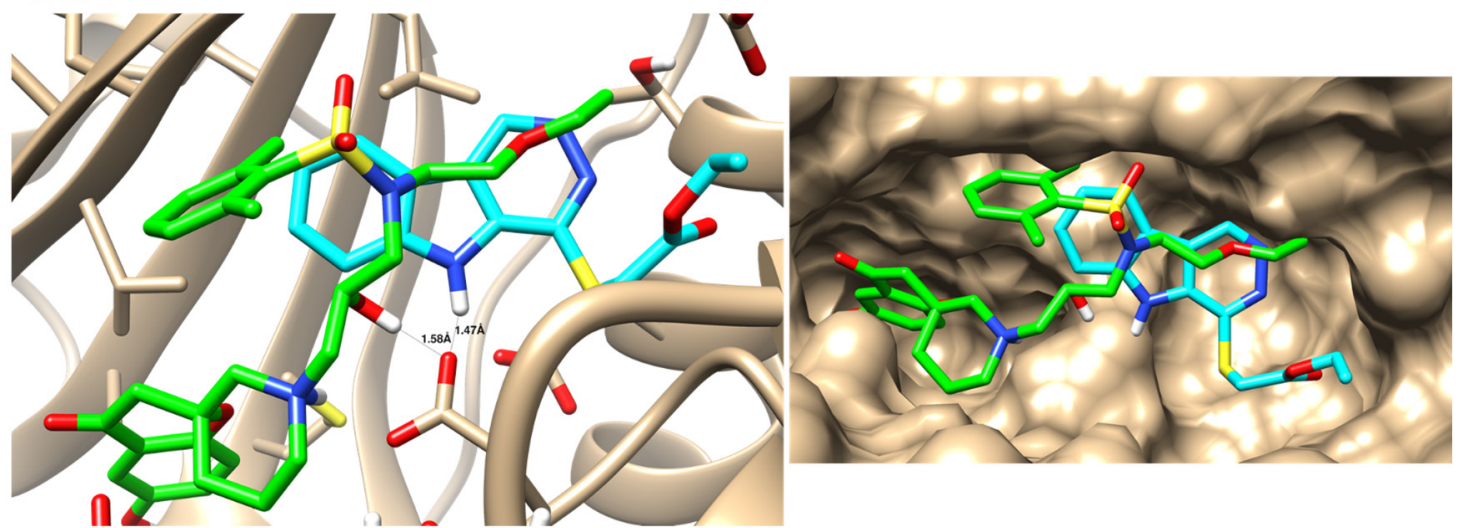

Figure 6. Binding disposition and ligand-receptor interactions between the cocrystallized ligand (green-colored) and docked compound 6 (cyan-colored) inside the three proteins of EGFR (PDB = 1M17), PI3K (5JHB), and AKT (PDB = 3QKK). The 3D images were obtained using Chimera. Compound $\mathbf{6}$ and the cocrystallized ligands are compared for highlighting the interaction binding mode inside the protein active sites and the lipophilic interactions with lipophilic amino acids.

\section{Conclusions}

New alkylsulfanylpyridazino[4,5-b]indole compounds, i.e., compounds 4-6, were synthesized. A reaction involving a new alkylsulfanyl ester, i.e., ester 6, afforded the synthesis of hydrazide 7. Among the synthesized compounds, compound 6 exhibited the most promising cytotoxicity toward MCF-7 cells with an $\mathrm{IC}_{50}$ value of $12 \mu \mathrm{M}$. Moreover, it exhibited promising inhibition activity toward EGFR and its downstream PI3K-AKT 
pathway, which suggests that it is a multitarget compound. Additionally, it increased apoptosis 47.98 -fold in MCF-7 cells and increased total apoptosis by $38.87 \%$. Hence, compound 6 is recommended as an anti-breast cancer chemotherapeutic due to its effects on the EGFR-PI3K-AKT pathway.

Supplementary Materials: The following supporting information can be downloaded at https: / / www.mdpi.com/article/10.3390/cryst12030353/s1, Cif file of compound 6; Figure S1: ${ }^{1} \mathrm{H}$ NMR of 2; Figure S2: ${ }^{13} \mathrm{C}$ NMR of 2; Figure S3: ${ }^{1} \mathrm{H}$ NMR of 3; Figure S4; ${ }^{13} \mathrm{C}$ NMR of 3; Figure S5: ${ }^{1} \mathrm{H}$ NMR of 4; Figure S6: ${ }^{13} \mathrm{C}$ NMR of 4; Figure S7: ${ }^{1} \mathrm{H}$ NMR of 5; Figure S8: ${ }^{13} \mathrm{C}$ NMR of 5; Figure S9: ${ }^{1} \mathrm{H}$ NMR of 6; Figure S10: ${ }^{13} \mathrm{C}$ NMR of 6; Figure S11: ${ }^{1} \mathrm{H}$ NMR of 7; Figure S12: ${ }^{13} \mathrm{C}$ NMR of 7 .

Author Contributions: Conceptualization, E.E.S. and A.T.A.B.; data curation, M.H.; formal analysis, M.H.; investigation, A.T.A.B. and E.E.S.; methodology, E.E.S. and A.T.A.B.; software, M.H.; visualization, M.H.; funding acquisition, E.E.S. and I.O.A.; writing-original draft, A.T.A.B., E.E.S., I.O.A. and M.H. All authors have read and agreed to the published version of the manuscript.

Funding: This research was funded by the Deanship of Scientific Research at Jouf University, K.S.A., grant number No. (DSR2020-04-1536).

Data Availability Statement: The data presented in this study are available on request from the corresponding author.

Acknowledgments: The authors extend their appreciation to the Deanship of Scientific Research at Jouf University for funding this work through research grant No. (DSR2020-04-1536).

Conflicts of Interest: The authors declare no conflict of interest.

\section{References}

1. Al-Thiabat, M.G.; Saqallah, F.G.; Gazzalii, A.M.; Mohtar, N.; Yap, B.K.; Choong, Y.S.; Wahab, H.A. Heterocyclic Substitutions Greatly Improve Affinity and Stability of Folic Acid towards FR $\alpha$. an In Silico Insight. Molecules 2021, 26, 1079. [CrossRef] [PubMed]

2. Bray, F.; Ferlay, J.; Soerjomataram, I.; Siegel, R.L.; Torre, L.A.; Jemal, A. Global cancer statistics 2018: GLOBOCAN estimates of incidence and mortality worldwide for 36 cancers in 185 countries. CA Cancer J. Clin. 2018, 68, 394-424. [CrossRef] [PubMed]

3. Bruel, A.; Bénéteau, R.; Chabanne, M.; Lozach, O.; Le Guevel, R.; Ravache, M.; Bénédetti, H.; Meijer, L.; Logé, C.; Robert, J.M. Synthesis of new pyridazino[4,5-b]indol-4-ones and pyridazin-3(2H)-one analogs as DYRK1A inhibitors. Bioorg. Med. Chem. Lett. 2014, 24, 5037-5040. [CrossRef] [PubMed]

4. Martins, P.; Jesus, J.; Santos, S.; Raposo, L.R.; Roma-Rodrigues, C.; Baptista, P.V.; Fernandes, A.R. Heterocyclic anticancer compounds: Recent advances and the paradigm shift towards the use of nanomedicine's tool box. Molecules 2015, 20, 16852-16891. [CrossRef] [PubMed]

5. Afzal, O.; Kumar, S.; Haider, M.R.; Ali, M.R.; Kumar, R.; Jaggi, M.; Bawa, S. A review on anticancer potential of bioactive heterocycle quinoline. Eur. J. Med. Chem. 2015, 97, 871-910.

6. Sravanthi, T.; Manju, S. Indoles-A promising scaffold for drug development. Eur. J. Pharm. Sci. 2016, 91, 1-10. [CrossRef]

7. Panathur, N.; Gokhale, N.; Dalimba, U.; Venkat Koushik, P.; Yogeeswari, P.; Sriram, D. Synthesis of novel 5-[(1,2,3-triazol-4yl)methyl]-1-methyl-3H-pyridazino[4,5- $b$ ]indol-4-one derivatives by click reaction and exploration of their anticancer activity. Med. Chem. Res. 2016, 25, 135-148. [CrossRef]

8. Monge, A.; Aldana, I.; Alvarez, T.; Losa, M.J.; Font, M.; Cenarruzabeitia, E.; Lasheras, B.; Frechilla, D.; Castiella, E.; FernandezAlvarez, E. 1-Hydrazino-4-(3,5-dimethyl-1-pyrazolyl)-5H-pyridazino[4,5-b]indole. A new antihypertensive agent. Eur. J. Med. Chem. 1991, 26, 655-658. [CrossRef]

9. Font, M.; Monge, A.; Cuartero, A.; Elorriaga, A.; Martínez-Irujo, J.J.; Alberdi, E.; Santiago, E.; Prieto, I.; Lasarte, J.J.; Sarobe, P.; et al. Indoles and pyridazino[4,5-b]indoles as nonnucleoside analog inhibitors of HIV-1 reverse transcriptase. Eur. J. Med. Chem. 1995, 30, 963-971. [CrossRef]

10. Bruel, A.; Logé, C.; De Tauzia, M.-L.; Ravache, M.; Le Guevel, R.; Guillouzo, C.; Lohier, J.-F.; Santos, J.S.O.; Lozach, O.; Meijer, L.; et al. Synthesis and biological evaluation of new 5-benzylated 4-oxo-3,4-dihydro-5H-pyridazino[4,5-b]indoles as PI3K $\alpha$ inhibitors. Eur. J. Med. Chem. 2012, 57, 225-233. [CrossRef] [PubMed]

11. Monge, A.; Aldana, I.; Alvarez, T.; Font, M.; Santiago, E.; Latre, J.A.; Bermejillo, M.J.; Lopez-Unzu, M.J.; Fernandez-Alvarez, E. New 5H-pyridazino[4,5-b]indole derivatives. Synthesis and studies as inhibitors of blood platelet aggregation and inotropics. J. Med. Chem. 1991, 34, 3023. [CrossRef] [PubMed]

12. Nantka-Namirski, P.; Ozdowska, Z. 2-Carbethoxyindole derivatives. I. Synthesis of 8-alkoxy- and 8,9-benzo-3H-pyridazino(4,5-b) indol-4-ones. Acta Pol. Pharm. 1972, 29, 9-15. [PubMed]

13. Evanno, Y.; Dubois, L.; Sevrin, M.; Marguet, F.; Froissant, J.; Bartsch, R.; Gille, C. 4-oxo-3,5-dihydro-4H-pyridazino[4,5-b]indole1acetamide derivatives (CA 2298522 A1). Chem. Abstr. 1999, 130, 68385. 
14. Radini, I.; El-Kashef, H.; Haider, N.; Farghaly, A.-R. Synthesis and functionalization of some new pyridazino[4,5-b]indole derivatives. ARKIVOC 2016, 101, 117. [CrossRef]

15. Wróbel, A.; Drozdowska, D. Recent Design and Structure-Activity Relationship Studies on the Modifications of DHFR Inhibitors as Anticancer Agents. Curr. Med. Chem. 2021, 28, 910-939. [CrossRef] [PubMed]

16. Raimondi, M.V.; Randazzo, O.; La Franca, M.; Barone, G.; Vignoni, E.; Rossi, D.; Collina, S. DHFR inhibitors: Reading the past for discovering novel anticancer agents. Molecules 2019, 24, 1140. [CrossRef] [PubMed]

17. Jendele, L.; Krivak, R.; Skoda, P.; Novotny, M.; Hoksza, D. PrankWeb: A web server for ligand binding site prediction and visualization. Nucleic Acids Res. 2019, 47, W345-W349. [CrossRef]

18. Vin, V.; Leducq, N.; Bono, F.; Herbert, J.M. Binding characteristics of SSR180575, a potent and selective peripheral benzodiazepine ligand. Biochem. Biophys. Res. Commun. 2003, 310, 785-790. [CrossRef]

19. Avan, I.; Güven, A.; Güven, K. Synthesis and antimicrobial investigation of some 5H-pyridazino[4,5-b]indoles. Turk. J. Chem. 2013, 37, 271-291.

20. Vasir, J.K.; Labhasetwar, V. Targeted Drug Delivery in Cancer Therapy. Technol. Cancer Res. Treat. 2005, 4, 363-374. [CrossRef]

21. Salama, E.E. Synthesis of new 2-amino-1,3,4-oxadiazole derivatives with anti-salmonella typhi activity evaluation. BMC Chem. 2020, 14, 30. [CrossRef] [PubMed]

22. Zaryouh, H.; De Pauw, I.; Baysal, H.; Peeters, M.; Vermorken, J.B.; Lardon, F.; Wouters, A. Recent insights in the PI3K/Akt pathway as a promising therapeutic target in combination with EGFR-targeting agents to treat head and neck squamous cell carcinoma. Med. Res. Rev. 2022, 42, 112-155. [CrossRef]

23. Fedele, M.; Cerchia, L.; Chiappetta, G. The epithelial-to-mesenchymal transition in breast cancer: Focus on basal-like carcinomas Cancers 2017, 9, 134. [CrossRef] [PubMed]

24. Jia, L.Y.; Shanmugam, M.K.; Sethi, G.; Bishayee, A. Potential role of targeted therapies in the treatment of triple-negative breast cancer. Anti-Cancer Drugs 2016, 27, 147-155. [CrossRef]

25. Wang, C.; Kar, S.; Lai, X.; Cai, W.; Arfuso, F.; Sethi, G.; Lobie, P.E.; Goh, B.C.; Lim, L.H.; Hartman, M.J. Triple negative breast cancer in Asia: An insider's view. Cancer Treat. Rev. 2018, 62, 29-38. [CrossRef] [PubMed]

26. Sharma, D.; Kumar, S.; Narasimhan, B. Estrogen alpha receptor antagonists for the treatment of breast cancer: A review. Chem. Cent. J. 2018, 12, 107. [CrossRef] [PubMed]

27. Liu, J.; Ming, B.; Gong, G.H.; Wang, D.; Bao, G.L.; Yu, L.J. Current research on anti-breast cancer synthetic compounds. RSC Adv. 2018, 8, 4386-4416.

28. Mostafa, A.S.; Gomaa, R.M.; Elmorsy, M.A. Design and synthesis of 2-phenyl benzimidazole derivatives as VEGFR-2 inhibitors with anti-breast cancer activity. Chem. Biol. Drug Des. 2019, 93, 454-463. [CrossRef] [PubMed]

29. Branowska, D.; Lawecka, J.; Sobiczewski, M.; Karczmarzyk, Z.; Wysocki, W.; Wolińska, E.; Olender, E.; Miroslaw, B.; Perzyna, A.; Bielawska, A.; et al. Synthesis of unsymmetrical disulfanes bearing 1,2,4-triazine scaffold and their in vitro screening towards anti-breast cancer activity. Mon. Chem.-Chem. Mon. 2018, 149, 1409-1420. [CrossRef]

30. Al-Warhi, T.; Sabt, A.; Elkaeed, E.B.; Eldehna, W.M. Recent advancements of coumarin-based anticancer agents: An up-to-date review. Bioorg. Chem. 2020, 103, 104163. [CrossRef] [PubMed]

31. Mosmann, T. Rapid Colorimetric Assay for Cellular Growth and Survival: Application to Proliferation and Cytotoxicity Assays. J. Immunol. Methods 1983, 65, 55-63. [CrossRef]

32. ElZahabi, H.S.A.; Nafie, M.S.; Osman, D.; Elghazawy, N.H.; Soliman, D.H.; EL-Helby, A.A.H.; Arafa, R.K. Design, Synthesis and Evaluation of New Quinazolin-4-One Derivatives as Apoptotic Enhancers and Autophagy Inhibitors with Potent Antitumor Activity. Eur. J. Med. Chem. 2021, 222, 113609. [CrossRef] [PubMed]

33. Gad, E.M.; Nafie, M.S.; Eltamany, E.H.; Hammad, M.S.A.G.; Barakat, A.; Boraei, A.T.A. Discovery of New Apoptosis-Inducing Agents for Breast Cancer Based on Ethyl 2-Amino-4,5,6,7-Tetra Hydrobenzo[b]Thiophene-3-Carboxylate: Synthesis, In Vitro, and In Vivo Activity Evaluation. Molecules 2020, 25, 2523. [CrossRef]

34. Boraei, A.T.A.; Soliman, S.M.; Haukka, M.; Salama, E.E.; Sopaih, M.; Barakat, A.; Sarhan, A.A.M. Straightforward green synthesis of indeno-furan carboxylates from ninhydrin and $\beta$-ketoesters: X-ray crystal structure, Hirshfeld and DFT investigations. J. Mol. Struct. 2022, 12255, 132433. [CrossRef]

35. Sarhan, A.A.M.; Boraei, A.T.A.; Barakat, A.; Nafie, M.S. Discovery of Hydrazide-Based Pyridazino[4,5- $b$ ]Indole Scaffold as a New Phosphoinositide 3-Kinase (PI3K) Inhibitor for Breast Cancer Therapy. RSC Adv. 2020, 10, 19534-19541. [CrossRef]

36. Nafie, M.S.; Amer, A.M.; Mohamed, A.K.; Tantawy, E.S. Discovery of Novel Pyrazolo[3,4-b]Pyridine Scaffold-Based Derivatives as Potential PIM-1 Kinase Inhibitors in Breast Cancer MCF-7 Cells. Bioorg. Med. Chem. 2020, 28, 115828. [CrossRef]

37. Nafie, M.S.; Arafa, K.; Sedky, N.K.; Alakhdar, A.A.; Arafa, R.K. Triaryl Dicationic DNA Minor-Groove Binders with Antioxidant Activity Display Cytotoxicity and Induce Apoptosis in Breast Cancer. Chem.-Biol. Interact. 2020, 324, 109087. [CrossRef] [PubMed]

38. Nafie, M.S.; Khodair, A.I.; Hassan, H.A.Y.; El-Fadeal, N.M.A.; Bogari, H.A.; Elhady, S.S.; Ahmed, S.A. Evaluation of 2Thioxoimadazolidin-4-One Derivatives as Potent Anti-Cancer Agents through Apoptosis Induction and Antioxidant Activation: In Vitro and In Vivo Approaches. Molecules 2022, 27, 83. [CrossRef] [PubMed] 